OPEN ACCESS

Edited by:

Zhen Chen,

University of Strathclyde,

United Kingdom

Reviewed by:

Nadia Margaret Anderson, University of North Carolina at

Charlotte, United States Thomas Bock,

Technical University of Munich, Germany

${ }^{*}$ Correspondence: Søren Munch Lindhard sm/@civil.aau.dk

Specialty section:

This article was submitted to Construction Management,

a section of the journal

Frontiers in Built Environment

Received: 23 October 2018 Accepted: 19 September 2019 Published: 10 October 2019

Citation:

Larsen MSS, Lindhard SM

Brunoe TD, Nielsen K and Larsen JK (2019) Mass Customization in the House Building Industry: Literature Review and Research Directions.

Front. Built Environ. 5:115. doi: 10.3389/fbuil.2019.00115

\section{Mass Customization in the House Building Industry: Literature Review and Research Directions}

\author{
Maria Stoettrup Schioenning Larsen ${ }^{1}$, Søren Munch Lindhard ${ }^{2 *}$, Thomas Ditlev Brunoe ${ }^{1}$, \\ Kjeld Nielsen ${ }^{1}$ and Jesper Kranker Larsen ${ }^{1}$ \\ ${ }^{1}$ Department of Materials and Production, Aalborg University, Aalborg, Denmark, ${ }^{2}$ Department of Civil Engineering, Aalborg \\ University, Aalborg, Denmark
}

Mass customization is a manufacturing paradigm that enables customized and personalized design at a cost near mass production. Mass customization's ability to lower unit cost, increase quality, and shorten project duration for customized offerings is considered highly relevant for tomorrow's house building industry. Therefore, through a literature review, this research investigates state-of-the-art in mass customization in the house building industry from four perspectives: (1) mass customization in the house building industry, (2) modular and off-site construction, (3) construction supply chains, and (4) customer satisfaction. It is concluded that a great potential exists for applying mass customization in the house building industry. However, despite its potential, research on mass customization in the house building industry is sparse. In particular, research on developing the solution space and choice navigation tools is limited in this industry.

Keywords: customer satisfaction, house building industry, literature review, mass customization, modular construction, off-site construction, supply chains

\section{INTRODUCTION}

Cross-coordination in engineer-to-order industries such as shipbuilding and construction was, for some time, considered of significant importance to avoid budget overruns, deadline escalation, and insufficient quality (Mello et al., 2015). However, despite this focus, when looking into project performance in the construction industry, cost escalations, time overruns, and lack of quality often occur (Hanif et al., 2016). According to Nicholas and Steyn (2017), it is not uncommon that engineering projects experience up to $20 \%$ budget overruns. This is also supported by the findings of Love (2002), who found average cost overruns to be 12.7\%, and Flyvbjerg et al. (2002), who found average cost overruns to be $28 \%$. Delay is, like cost overruns, a huge challenge in the construction industry (Kazaz et al., 2012; Lindhard and Wandahl, 2014). Assaf and Al-Hejji (2006) reported time increases ranging from 10 to $30 \%$, which is similar to the findings of Olawale and Sun (2010), who reported between 10 and 40\% time overrun. Josephson and Hammarlund (1999) studied the costs of failure and rework in construction projects and found the associated costs to be between 2.3 and $9.4 \%$ of the total construction costs. Therefore, when considering the fierce competition in a market particularly focused on costs, it is relevant to further explore opportunities for improving the production performance in the construction industry and thus the management and control hereof. 
During the first half of the twentieth century, attempts were made to introduce and implement industrialization techniques in the construction industry to produce family houses and apartments. According to Sacks and Partouche (2009), the construction of the Empire State Building is an archetype of mass construction given its extraordinary short construction duration. According to Gann (1996), the industrialized construction in the first half of the twentieth century was inspired by Ford's assembly line of cars. The benefits of and motivation for using industrialized construction techniques at this time were lower unit costs and shortened construction time, which at this point in time were highly relevant since the Second World War had implied a housing shortage (Anson et al., 2002). However, a combination of too much standardization to lower unit costs, shortage of quality, and high maintenance costs caused a negative perception on industrialized construction (Nadim and Goulding, 2011). According to Ramaji and Memari (2016), this perception of cheap and low-quality housing in relation to industrialized construction still exists. Therefore, to find a balanced trade-off between industrialization and customization, Halman et al. (2008) argued that the construction industry needs to apply concepts that allow greater customization. An appropriate solution approach should, therefore, allow greater customization while securing low unit costs and high product quality (Pine et al., 1993). Mass customization attempts to fulfill these contradictory requirements (Pine, 1993).

\section{Mass Customization}

Mass customization is a business strategy combining the opposing production theories mass production and customization. Mass customization is taking its point of departure in economics of scale using mass production to produce units at a low cost while at the same time allowing flexibility and individual customization of the product (Barman and Canizares, 2015). According to Pine (1993) the purpose of mass customization "is to develop, produce, marketing, and deliver affordable goods and services with enough variety and customization that nearly everyone finds exactly what they want." Buffington (2011) stated that a lack of a clear taxonomic classification and a clear definition of mass customization most likely is the reason why mass customization generally has not been an alternative to mass production yet. According to Salvador et al. (2009), the ability to adopt mass customization is based on three fundamental capabilities: (1) solution space development, which aligns the variety of product attributes with the variety of customer needs; (2) robust process design, which structures the organizational and value chain resources to fulfill customer needs; and (3) choice navigation, which supports customers' decisions when defining their own solution while reducing choice complexity.

To approach mass customization and avoid pitfalls, Gilmore and Pine (1997) suggested four approaches of mass customization: collaborative customization, adaptive customization, cosmetic customization, and transparent customization. As an alternative to this, Lampel and Mintzberg (1996) argued for five mass customization approaches, which are pure standardization, segmented standardization, customized standardization, tailored standardization, and pure customization. According to Berman (2002), design flexibility is reduced in mass-customized products compared with, for example, engineer-to-order products to obtain economies of scale in the production. Therefore, the sacrifice of the customer's design flexibility needs to be accounted for when considering to implement a mass customization strategy.

Franke et al. (2010) demonstrated that mass customization creates an "I designed myself" effect where a personal attachment to the final product design makes the customer significantly more willing to pay extra for the product because it is customized. Tseng and Piller (2003) have reached the same conclusion on similar studies showing an increased willingness to pay extra for customized products.

Contradictory to the positive effects of mass customization, such as increased flexibility and efficiency, Huang et al. (2010) demonstrate that a company's organizational structure affects the company's mass customization capabilities. To give the customers the opportunity for flexibility and individual customization, product modularity is often considered to be the cornerstone of mass customization (Coronado et al., 2004). However, whether modularity can be considered the cornerstone of mass customization is debated among researchers given that some business services and products do not require a modular structure to apply mass customization as a business strategy. Decomposition of a complex system into smaller parts or modules to make it more manageable furthermore gives the designer the opportunity to develop a higher level of product variety, which, however, shares commonalities (Jose and Tollenaere, 2005). Huang and Kusiak (1998) defined engineering modularity as “... used to describe the use of common units to create product variants. It aims at the identification of independent, standardized, or interchangeable units to satisfy a variety of functions." According to Erixon (1998), configurable products can be divided into three modular concepts: slot modularity, bus modularity, and sectional modularity. The three concepts differ in the way the modules interact with one another, which means that applying modularity sets high requirements for aligning product and product variance with the applied type of architecture.

According to Barman and Canizares (2015), the strength of mass customization is the use of economics of scale to secure a low unit cost while at the same time providing customers with the opportunity to customize the offering (Jensen et al., 2017). However, even though mass customization allows individual product adjustments, these are limited and bound to pre-defined structures (Berman, 2002). Nevertheless, the possibility of making changes and providing individual solutions is valuable compared with a mass production strategy. By studying the house building industry's use of mass customization, Nahmens and Bindroo (2011) concluded that the house building industry has not yet achieved the ideal level of mass customization. In addition, Bock (2015) argued that traditional on-site construction techniques have reached their technical limitations and sees trends of stagnation. Therefore, changing market competition 
will most likely appear, as mass customization will take further market power in the future and utilize the benefits of off-site construction.

A good example of mass customization in the house building industry is from a construction company located in the northern part of Denmark. The company, among others, produces social housing, which is made of standard modules containing, for example, a kitchen or a bathroom. The modules are produced off-site and afterwards assembled into one complete house onsite. In these social housing projects, several identical houses are produced. The houses have standard layouts as regards placement of kitchen, bathroom, wardrobe, and technical room; however, the partition of bedrooms is flexible and is not determined beforehand. This means that the customers can customize this part of the interior layout of the individual houses according to their individual needs after the on-site assembly of the standardized modules and in that way obtain a customized interior layout.

Research on and application of mass customization in the construction and house building industry are sparse (Nielsen et al., 2017) despite that a significant amount of research on mass customization exists and that mass customization as a business strategy has revolutionized other industries, such as the manufacturing industry. Therefore, this literature review seeks to examine existing research on mass customization in the house building industry and its interrelated concepts to identify research gaps in the body of knowledge for future research studies to explore.

The article is structured as follows: In section Research Methodology, the applied research methodology is presented; section Results presents the results of the literature review; and lastly, in section Discussion, findings are discussed and future research directions are presented.

\section{RESEARCH METHODOLOGY}

This section presents the applied research methodology for the literature review. The literature was retrieved in three phases. First, a literature search was conducted in 2016; afterwards, revisions from experts implied additional research to be included in the research; and lastly, it was determined to update the research to include the most recent publications in the field. The literature search procedure is described in detail in this section.

To ensure that the process of conducting the literature review was effective and resulted in providing a firm foundation to the research field (Levy and Ellis, 2006), the literature review was performed using a three-stage procedure proposed by Levy and Ellis (2006). The three stages are input, processing, and output. In the input stage, articles for the literature review were retrieved. This process is further described in this section. The selected articles were used as input for the processing stage, which consists of analyses of the articles' content. The result of the processing stage is presented in section Results. Based on the results of the processing stage, the findings of the literature review are discussed, and future research directions are presented in section Discussion, which constitute the output stage.
The starting point for this literature review was taken in 63 articles, which the authors were familiar with from previous research and which had topics that were considered relevant for this research. Based on the 63 articles, a draft was derived for relevant keywords to use in the literature search. The keywords represented mass customization or off-site construction because off-site construction is a prerequisite for introducing industrialization to the industry (Gann, 1996), which is a prerequisite for being able to mass customize. The keywords were discussed with the authors of this article who have research experience in mass customization in the building industry. Based on this discussion, the first search string for the literature search was derived, as follows:

("Choice navigation" OR "Configuration" OR "Configuration
process" OR "Consumer choice" OR "Customer preferences" OR
"Customer satisfaction" OR "Customer value" OR "Customization"
OR "Customized house design" OR "Customized housing"
OR "Individualization" OR "Manufacturing processes" OR
"Mass custom design" OR "Mass custom home" OR "Mass
Customization" OR "Modularization" OR "Personalization" OR
"Platform concept" OR "Platforms" OR "Process innovation"
OR "Product architecture" OR "Product configuration" OR
"Product design" OR "Product families" OR "Product family"
OR "Product management" OR "Product model" OR "Product
platform" OR "Robust process design" OR "Solution space
development") AND ("Affordable home" OR "Apartment building"
OR "Automation in construction" OR "Building industry" OR
"Building production" OR "Building system" OR "Buildings" OR
"Construction industry" OR "Design system" OR "Homebuilding"
OR "House building industry" OR "Housebuilding" OR "Housing"
OR "Industrial construction" OR "Industrialized housing" OR
"Low-cost housing" OR "Manufactured homes" OR "Modular
construction" OR "Offsite production" OR "Off-site production"
OR "Pre-assembly" OR "Precast construction" OR "Prefabricated
buildings" OR "Prefabricated construction" OR "Prefabrication"
OR "Quality home" OR "Residential" OR "Residential buildings"
OR "Residential construction" OR "Standardization" OR
"Standardized house types")

The search string was searched in Web of Science. The results were limited to topics relevant for the research area, for example, engineering civil, management, engineering manufacturing, and operations research management science, whereas topics that had no relevance to the topic were excluded. These were, among others, telecommunications, engineering chemical, physics applied, and veterinary sciences. The search was furthermore restricted to journal articles. Based on titles, the remaining search hits were reviewed, which resulted in 77 relevant peer-reviewed journal articles. From these 77 articles, new keywords were made, and a second search string was derived, as follows: (TS=(("Building system" OR "Buildings" OR "Construction" OR
"Construction industry" OR "Construction management" OR "Cost
and schedule" OR "Europe" OR "Evolution" OR "Germany" OR
"High-rise building" OR "Hong Kong SAR" OR "House building"
OR "Housebuilding industry" OR "Housing" OR "Industrialized
housing" OR "Innovation" OR "Japan" OR "Lean construction" 
TABLE 1 | Article identification phases.

\begin{tabular}{lc}
\hline Article identification phase & Total articles included after phase \\
\hline Previous research & 63 \\
First search string & 140 \\
Second search string & 282 \\
Title review & 239 \\
Abstract review & 188 \\
Relevant to research area & 66 \\
Expert input & 71 \\
Forward search & 91
\end{tabular}

OR "Offsite production" OR "Performance evaluation" OR "Preassembly" OR "Prefabrication" OR "Project planning and design" OR "Project success" OR "Residential" OR "Residential buildings" OR "Service quality" OR "Steel” OR "Survey" OR "U.K") AND ("Automation" OR "Consumer choice" OR "Customer needs" OR "Customer satisfaction" OR "Customer service" OR "Customization" OR "Digital fabrication" OR "Engineer-to-order (ETO)" OR "Integrated design" OR "Mass custom design" OR "Mass customization" OR "Mass customization (MC)" OR "Models" OR "Modularity" OR "Modularization" OR "Product architecture" OR "Product configuration" OR "Product platform" OR "Production planning" OR "Standardization" OR "Strategic planning" OR "Supply chain management")))

This search string was searched in Web of Science, SpringerLink, and Scopus. The results were limited to publications in research areas relevant to the literature review and journal articles as previously described. The outcome of the search was additional 142 peer-reviewed journal articles. Including the initial 63 preidentified articles, 282 peer-reviewed articles were identified in total after the first step of the literature search. The 282 articles were afterwards reviewed on the basis of title to identify duplicates and assess the articles' relevance to the research area. This resulted in eliminating 43 articles from the initial 282. Based on a review of abstracts of the remaining 239 articles to assess the context of the articles, 48 articles, and three additional duplicates were eliminated. The final number of articles included in this research was found in three steps. First, the 188 articles found through the literature search were assessed in regard to their relevance to the research area. Only research with utmost relevance was included, which resulted in 66 articles being selected for this research. Afterwards, expert inputs were provided, which implied that related research from other geographical areas presented in five journal articles was included, which increased the number of articles to 71. Lastly, it was determined to conduct a forward search of the 71 articles to make the research presented in this article up-to-date. Therefore, articles published between 2016 and 2019 referring to the 71 articles were checked for relevance. This search implied additional 20 articles to be included in the literature review, which means that this literature review is based on 91 articles in total. The number of articles identified in each step is summarized in Table 1.
To map the existing body of knowledge and construct a discussion and a synthesis in the output stage, the identified 91 articles were categorized into four research areas: (1) mass customization in the house building industry, (2) modular and off-site construction, (3) construction supply chains, and (4) customer satisfaction. Mass customization in the house building industry presents findings related to mass customization in construction of houses and apartments, modular and off-site construction analyses the use of modular and offsite construction, findings related to supply chains in the construction industry are presented in construction supply chains, and customer satisfaction analyses research on customer satisfaction when using mass customization, and modular and off-site construction.

\section{RESULTS}

The articles were analyzed on the basis of the previously described four categories. Together, the analyses of the four research areas aim to establish an understanding of state-ofthe-art research on mass customization in the house building industry. As mass customization is an interdisciplinary research field, it is highly relevant to include diverse research foci like design, operations management, or supply chain management to expose the potential for utilizing mass customization in the house building industry. The analysis results for each of the four categories are presented in the following.

\section{Mass Customization in the House Building Industry}

Production in the house building industry is, according to Roy et al. (2003), characterized by a long and labor-intensive building process where it is difficult to perform quality control. Consequently, Ball (1999) argued that to be more successful in the market, the house building industry should come up with new business strategies that have a higher focus on innovation. Barlow (1999) furthermore suggested that the house building industry needs to apply a more proactive approach to innovation to lower costs and at the same time improve quality and functionality. For that reason, Veenstra et al. (2006) argued that the use of a platform-based strategy has proven to be a successful compromise between standardized components utilizing economics of scale while at the same time allowing variety and customization in many industries. However, Senghore et al. (2004) argued that many house production plants fail to produce at their intended maximum capacity and production rate because the production process, first, is too laborintensive rather than technology based and, second, each house at the assembly line is too unique; thus, a lack of repetition exists. Third, innovation differences between on-site- and offsite-constructed houses are not directly applicable even though similar materials are used in both processes. To create a stable production flow to achieve enhanced productivity and reduced lead times and defect eliminations, Yu et al. (2009) suggested applying a systems view instead of focusing on sub-optimizations in the house construction process. 
According to Frutos and Borenstein (2003), mass customization is also applicable in the construction industry. They demonstrated that buyers of apartments demand customized offerings, which means that to secure customer satisfaction, solutions should accommodate the unique needs of the customers. Schoenwitz et al. (2012) studied within 16 projects over 35 years which components German house customers preferred to customize. They identified a strong desire to customize the categories sanitary, internal design, and facades. Moreover, additional services, house technology, and heating were the categories least desired to be customized.

Thuesen and Hvam (2011) conducted a case study of a German housing platform. The study revealed that the organization's ability to handle complexity, its commitment, and its focus on target cost and customer value implied a $30 \%$ reduction on product cost. This high cost reduction enabled the company to sell houses to customers who could otherwise not afford it. Nahmens and Mullens (2009) studied the relationship between product variety and lean production to enable mass customization in the house building industry. Their results showed that product diversity does not necessarily complicate the implementation of lean production. However, Nahmens and Bindroo (2011) argued that the house building industry has not yet achieved the ideal use of mass customization. Yet, according to Boafo et al. (2016), the potential for growth in the building industry by using pre-fabricated modules is no longer just an option in theory but has become a practical realization.

The automotive industry has been through a process in which lean production principles were gradually adopted and is now moving toward mass customization as the next paradigm (Benros and Duarte, 2009). According to Bock (2015), several indicators show that existing on-site construction techniques have reached their limits owing to the stagnation and technical limitations experienced by the industry. In addition, Daud et al. (2012) concluded that mass-customized housing is a promising concept in the Malaysian house building industry. Furthermore, they argue that high competition in housing and developer markets has composed an incentive for moving the focus from customized housing to mass-customized housing. Lastly, Winch (2003) argued that all assembly industries including construction go through the stages concept, design, planning and control, manufacture, and assembly. The only difference is that construction projects' assembly stage is on-site instead of the product being shipped to the end-user later in the process like other assembly industries (Winch, 2003). Furthermore, in a mass-customized offering, the design phase is, according to Jensen et al. (2012), replaced by a configuration process. In this process, the product is customized from a set of standard modules (Jensen et al., 2012). Alwisy et al. (2018) proposed a methodology for automating the design and drafting processes of manufacturing modular buildings to reuse information and improve the processes of design and drafting in modular building manufacturing. According to Salama et al. (2017), architects lack knowledge on the limitations in the module manufacturing process for which reason they developed a methodology that considers project conditions in the design of module configurations. To integrate manufacturing and assembly constraints in the design phase of pre-fabricated buildings, Yuan et al. (2018) suggested using a design for manufacture and assembly-oriented parametric design.

\section{Modular and Off-Site Construction}

The analysis of the articles categorized as "modular and off-site construction" is presented in this section. Modular and off-site construction refers to constructions that are modular and/or produced off-site. The content of the articles has been divided into three additional topics: definition, historical description, and pros and cons of modular and off-site construction. Through these topics, state-of-the-art research on modular and off-site construction is accounted for.

\section{Defining Modular and Off-Site Construction}

Off-site production is an increasingly applied technique that moves on-site production to a controlled, stable factory environment (Arashpour et al., 2015). Goodier and Gibb (2007) defined off-site construction as "manufacture and pre-assembly of component, elements or modules before installation into their final location." Gibb (1999) divided the level of off-site construction into four general levels: level 1 is simple component manufacturing and sub-assembly, level 2 is non-volumetric components, level 3 is volumetric components, and level 4 is modular building structures.

Höök and Stehn (2008) defined industrialized housing as "production in a closed factory environment where only assembly is performed at the construction site, with one evident process owner and a clear product goal of repetition in housing design and production." Thus, both off-site production and industrialized housing share the same vision of only assembly and installation of the final product at the final location regardless of the chosen level of off-site construction.

Numerous off-site production techniques are used in the construction industry today. The applied technique depends on project requirements and conditions such as climate protection, labor skills, quality level, and transportation of elements (Richard, 2005). However, despite several researchers studying the subject, different terminologies and definitions of similar offsite production techniques are present. Therefore, definitions of terminologies for off-site production techniques applied in the reviewed literature are presented in Table 2.

\section{Historical Perspective of Modular and Off-Site Construction}

The idea of using industrialized pre-fabrication for family housing is not new. Over the last century, both private- and public-funded examples of pre-fabricated projects produced with the diverse techniques are seen frequently (Anson et al., 2002). Particularly, the house building industry has improved its performance compared with that of normal scattered craft production in the building industry by learning from other industries such as the manufacturing industry (Gann, 1996). Onori et al. (2008) argued that the relative uniqueness of each building differentiates the "site production" used in the construction industry from "fixed position manufacturing" such as airplane or shipbuilding industries. Richard (2005) argued that 
TABLE 2 | Off-site production techniques and their definitions.

\begin{tabular}{|c|c|c|}
\hline $\begin{array}{l}\text { Off-site } \\
\text { production } \\
\text { technique }\end{array}$ & Definition & References \\
\hline Modularization & $\begin{array}{l}\text { "... the preconstruction of a complete } \\
\text { system away from the job site that is then } \\
\text { transported to the site. The modules are } \\
\text { large in size and possibly may need to be } \\
\text { broken down in to several smaller pieces } \\
\text { for transport ..." }\end{array}$ & Haas et al., 2000 \\
\hline Module & $\begin{array}{l}\text { "A module is physically manifested as a } \\
\text { construction unit that is part of a wider } \\
\text { system, which can be integrated through } \\
\text { pre-planned interfaces. These physical } \\
\text { modules are the result of, and can } \\
\text { facilitate, modularization in different } \\
\text { phases of the project. They may be } \\
\text { considered at different hierarchical levels } \\
\text { within the overall product architecture, } \\
\text { may be manufactured on or off-site, and } \\
\text { can be volumetric or non-volumetric." }\end{array}$ & $\begin{array}{l}\text { Gosling et al., } \\
2016\end{array}$ \\
\hline $\begin{array}{l}\text { Off-site } \\
\text { construction }\end{array}$ & $\begin{array}{l}\text { "... the manufacture and pre-assembly of } \\
\text { component, elements or modules before } \\
\text { installation into their final location ..." }\end{array}$ & $\begin{array}{l}\text { Goodier and } \\
\text { Gibb, } 2007\end{array}$ \\
\hline Pre-assembly & $\begin{array}{l}\text { "... a process by which various materials, } \\
\text { pre-fabricated components, and/or } \\
\text { equipment are joined together at a remote } \\
\text { location for subsequent installation as a } \\
\text { unit ..." }\end{array}$ & $\begin{array}{l}\text { Tatum et al., } \\
1987\end{array}$ \\
\hline Prefabrication & $\begin{array}{l}\text { "... a manufacturing process, generally } \\
\text { taking place at a specialized facility, in } \\
\text { which various materials are joined to form } \\
\text { a component part of a final installation ..." }\end{array}$ & $\begin{array}{l}\text { Tatum et al., } \\
1987\end{array}$ \\
\hline Standardization & $\begin{array}{l}\text { "... standardization is the use of the same } \\
\text { component in multiple products and is } \\
\text { closely linked to product variety." }\end{array}$ & Ulrich, 1994 \\
\hline $\begin{array}{l}\text { Industrialized } \\
\text { housing }\end{array}$ & $\begin{array}{l}\text { "... production in a closed factory } \\
\text { environment where only assembly is } \\
\text { performed at the construction site, with } \\
\text { one evident process owner and a clear } \\
\text { product goal of repetition in housing } \\
\text { design and production ..." }\end{array}$ & $\begin{array}{l}\text { Höök and Stehn, } \\
2008\end{array}$ \\
\hline
\end{tabular}

if today's cars were produced in a similar way as our buildings, very few people would be able to afford a car. Nevertheless, given the advantages of using pre-fabricated housing, it has so far only been the Japanese housing industry that has succeeded in transforming itself from a traditional construction industry to an industrialized production industry (Linner and Bock, 2012).

According to Gann (1996), architects such as Le Corbusier, Walter Gropius, Bemis, and Buckminster Fuller initiated the beginning of industrialized construction in the first half of the twentieth century. They were all strongly inspired by the manufacturing industry's success, particularly by the Ford car's assembly line. For example, the Le Corbusier's Dom-ino House is using a simple standardized column and beam structure with a flexible floor plan that creates the opportunity for moving internal walls independently of the structural design (Gann, 1996). However, according to Anson et al. (2002), the demand for industrialized housing was not urgent until after the Second World War, where the housing crisis as a result of the war was addressed using pre-fabricated timber-framed houses with aluminum clad. The second period of industrialized constructions arose as a result of the shortage of housing around the cities in the end of the 1950s (Anson et al., 2002). Therefore, high-rise industrialized pre-cast systems such as the Danish Larsen-Nielsen system developed in 1948 was used from 1950 and up until the 1960s (Anson et al., 2002). However, in 1968, the Ronan Point in London collapsed owing to a gas explosion, which resulted in much criticism of high-rise pre-cast systems. The critique was related to the quality level and maintenance costs associated with high-rise pre-cast systems, and as a consequence of this, the use of high-rise systems stopped (Anson et al., 2002).

The critique and skepticism of using modular and off-site construction are until today very common. However, Mahapatra et al. (2012) found a negative public perception of using wood to multistory properties in countries such as Germany and the UK but did not find this skepticism in Sweden. Mahapatra et al. (2012) explained this difference by the fact that $90 \%$ of the family houses in Sweden are wood framed, and for that reason, Swedes have a positive approach to using wood for multistory properties as well. According to Nadim and Goulding (2011), past unsuccessful examples of using off-site construction techniques have resulted in the European construction industry hesitating to embrace these techniques. Isaac et al. (2016) argued that the negative perceptions from many clients toward using pre-fabricated modules are stimulated by the high degree of standardization required to reduce unit costs to utilize economics of scale. Ramaji and Memari (2016) stated that modular off-site construction is still associated with cheap temporary housing of low quality. This statement is supported by Linner and Bock (2012), who stated that European pre-fabrication of buildings is mostly a market niche fulfilling the low-cost segment, whereas the Japanese pre-fabrication market focuses on the middle and high-end markets. Therefore, Halman et al. (2008) suggested that the construction industry needs to adopt concepts allowing a greater customer focus such as a platformbased approach. Yashiro (2014) stressed this point by arguing for a growing demand of individual customization using mass customization as an approach to create industrialized buildings, which accommodate customers' unique requirements.

\section{Pros and Cons of Modular and Off-Site Construction}

Several studies such as Gibb and Isack (2003), Goodier and Gibb (2007), and Jaillon and Poon (2010) have studied pros and cons of modular and off-site construction with different project partners and attributes. According to Nadim and Goulding (2011), the construction industry hesitates to apply modular and off-site construction techniques despite their well-documented benefits, and for that reason, the construction industry has not yet utilized the full potential of modular and off-site construction (Construction Industry Institute Research, 2009; O'connor et al., 2014; Nielsen et al., 2017). According to Ji et al. (2017), industrializing the construction industry in China will, in the long term, result in substantial benefits for both industry and public. However, in a survey targeting Chinese professionals, $\mathrm{Wu}$ et al. (2019) studied the support of off-site construction in China's 
building sector and found that $44 \%$ of the respondents believe that off-site construction should not become a widely applied technique owing to its multiple barriers.

Through modular housing designs, construction companies can use industrialization techniques and thus utilize the benefits of industrialization without compromising the opportunity to customize the offering to the customer. However, to exploit the benefits of industrialization, it is necessary to move the production off-site as is also seen in the manufacturing industry (Gann, 1996). By moving the production from on-site to offsite, this also entails additional benefits like independency on weather conditions as opposed to on-site production where weather conditions have a high impact on the production quality (Arashpour et al., 2015). Other advantages of modular and offsite construction are improvements in production time, costs, on-site safety, product quality, productivity, and environmental performance (Kamali and Hewage, 2016), for instance, by taking recycling of construction materials into account in the design (Minunnu et al., 2018). Chen and Lu (2018) furthermore found that an improved assembly process of standard, pre-produced components reduced the generation of waste in the construction process. In a survey, Sharafi et al. (2018) found that modular construction is the most preferred construction system in relation to reducing disturbance on-site and improving the reusability of materials. Modular construction is furthermore the most preferred construction system when evaluating the construction completion time.

According to Pan et al. (2008), house building companies that use modular and off-site construction techniques currently have small market shares. However, in the future, their market shares are likely to increase owing to a pressure on improving a combination of quality, cost, time, productivity, health, and safety. Linner and Bock (2012) reported that pre-fabrication techniques in European countries such as Germany have a market share of the housing market of up to $15 \%$. In Austria, the market share is $\sim 33 \%$, in France $\sim 5 \%$, and in Spain $\sim 5 \%$. Bergström and Stehn (2005) reported that $\sim 74 \%$ of Swedish detached timber-framed family houses built from 1990 to 2002 were produced at factories.

The benefits of using modular and off-site construction techniques depend according to Blismas et al. (2006) on a combination of the applied building methods and the individual project conditions. Blismas et al. (2006) argued that the decision to apply a specific construction technique is mostly cost based, which means that derived benefits by using off-site techniques such as health and safety, sustainability, management, and process effects are not taken into consideration. The three performance measurements-cost, time, and waste generationare, according to Jin et al. (2018), widely adopted for assessing pre-fabricated construction projects. According to Li et al. (2013), modular, off-site construction brings considerable reductions in construction time, waste, hazards, and injuries and improves quality control and safety.

Despite the many advantages of modular and off-site construction, there are also some downsides (Jiang et al., 2018). Li et al. (2013) presented four categories of risks encountered in modular construction that differ from risks of conventional projects. These are engineering, occupational and cultural, socioeconomic, and financial risks. Choi et al. (2019) found that the three largest barriers for using modular construction in urban environments are on-site access and storage, transportation, and logistics, and the distance between factory and site. Hwang et al. (2018) have identified five significant constraints that limit the adoption of off-site construction. These are requirements of additional coordination, additional planning, extra considerations of transportation and logistics, requirement of earlier commitment, and higher initial costs. Lu et al. (2018) have identified 13 factors that affect the implementation of prefabrication. The factors are grouped into political, economic, social, and technological factors, which should be considered to determine the optimal level of pre-fabrication. Li et al. (2019) found that constraint management is of vital importance in building information modeling for pre-fabricated houses.

Song et al. (2005) and Tam et al. (2007) found that a successful implementation of modular and off-site construction techniques requires early decision making and analyses based on the specific project's circumstances. Additionally, Goodier and Gibb (2007) found that a shorter on-site construction period and increased quality are the two major advantages of applying off-site construction techniques. However, the additional cost of off-site construction is the main barrier among suppliers, manufacturers, contractors, designers, and clients in the UK construction industry (Goodier and Gibb, 2007).

Jaillon and Poon (2009) found that pre-fabrication with a modular design and standard elements saves project time, and design and construction costs. They furthermore discovered that the associated effects of modular construction were improved quality, $20 \%$ reduction of construction time, 56\% less construction waste, and $9.5 \%$ reduction in noise, dust, and labor on-site. Lawson et al. (2011) demonstrated similar results in a case study in England. For that reason, there is evidence indicating that off-site construction techniques that use a platform approach across building projects can benefit from the advantages of modular and off-site construction (Halman et al., 2008).

\section{Construction Supply Chains}

Construction companies planning to use customer choices to compete in the market need to rethink the organization as a total process where the customer order decoupling point and its effect on the supply chain should be considered (Barlow et al., 2003). Doran and Giannakis (2011) found that supply chain integration is important for modular building solutions to compete with traditional on-site construction. Therefore, they suggest a relationship/supplier and an assessment/development mapping to accommodate this challenge. Looking into how supply chain management in the construction industry is defined, Love et al. (2004) suggested “... the network of facilities and activities that provide customer and economic value to the functions of design development, contract management, service and material procurement, materials manufacture and delivery, and facilities management." To map the supply chain in the house building industry, Halman and Voordijk (2012) suggested a framework based on the balanced scorecard. The 
framework consists of 35 corresponding indicators divided into five perspectives: financial, customer, internal business, external business, and innovation. The link between construction modularity and supply chain integration can, according to Pero et al. (2015), be traced back to Northern Europe's use of wooden houses and the Japanese house building industry's systematic use of non-volume and volume pre-assembled modules. In a case study of two American construction companies, Viana et al. (2017) found that both case companies use a modular supply chain design to support the construction of modular buildings.

The existing use of supply chain management in the construction industry shares many similarities with that of other engineer-to-order industries such as shipbuilding, oil and gas, and aerospace. According to Mello et al. (2015), the ability to coordinate effectively in engineer-toorder supply chains is significantly important to avoid cost overruns, delays, and insufficient quality. They furthermore discovered that the integration of engineering, production, and production capabilities is the most important to ensure successful coordination in engineer-to-order supply chains within the shipbuilding industry. After studying the house building industry's supply network of modular products, Hofman et al. (2009) argued that the alignment of product modules, and contractor and supplier relationships are dependent on four drivers: (1) the variety degree in customers' demand, (2) required supplier investment, (3) dependency of supplier knowledge, and lastly (4) the intentions of supplier and buyer relationships. Anvari et al. (2016) argued that separation of scheduling processes of manufacturing, transportation, and the final assembly of precast construction modules often results in delays and cost increases. In addition, they suggest that smalland medium-sized projects should use a multi-objective genetic algorithm to obtain the most advantageous solution instead.

The supply chain in the construction industry is very fragmented, and its procurement models reduce the level of collaboration and innovation. This means that, in general, the maturity level of supplier management in the construction industry is low (Liu et al., 2018). According to Behera et al. (2015), many project-based companies have standardized templates for their project management processes, but only few use similar templates for their supply chain processes. They argue that lack of standards concerning supply chain management is caused by lack of information sharing, continuous improvements, and learning in the construction industry. Liu et al. (2018) presented an assessment system for evaluating the maturity level of a construction company's supplier management to identify its weaknesses and, based on this, for developing improvement strategies.

\section{Customer Satisfaction}

A consequence of using pre-assembly construction and mass customization is that customer satisfaction and project success become more complex to measure than are engineer-to-order construction projects. Generally, construction project success is reached when a project is completed according to contractagreed deadline and budget, within specifications, and with customer satisfaction (Nguyen et al., 2004). However, according to Gibb and Isack (2003), customers buying pre-assembled construction projects have performance expectations beyond project parameters such as project duration, budget, and quality. They find that a combination of project performance parameters such as project duration, budget, quality, productivity, improved health and safety, and less congestion on-site are the main drivers for customers applying pre-assembled construction. According to $\mathrm{Du}$ et al. (2006), the challenge for companies applying product customization is to produce customized products that ensure customer satisfaction while complying with the company's capabilities. For that reason, alignment to customer demand is of great importance when allowing customization. At the same time, product elements that customers do not require to be customized should be standardized to utilize economics of scale. To support the designers in the design process, Moghimi et al. (2017) developed a priority list of the most effective design strategies to accommodate customer requirements in regard to design of the interior, exterior, indoor environment, and organization of the house. Adinyira et al. (2018) found that reduction of energy consumption and energy costs, increase of energy efficiency and return on investment, and provision of a secure energy supply were the five most important stakeholder requirements for building energy-efficient massproduced houses in Ghana.

Until today, the house building industry primarily relies on monotonous design that does not necessarily fulfill customer demand and expectations (Lee and Ha, 2013). Craig and Roy (2004) argued that business drivers in the house building industry, compared with the manufacturing industry, have reduced focus on customer needs and instead focused on price inflation. Warren-Myers and Heywood (2018) studied companies building mass-produced homes and found that the customer satisfaction deteriorates after signing the initial contract, which is caused by companies' lack of focus on customer satisfaction due to a market competition focused on reducing costs. Consequently, Leishman and Warren (2006) argued that the house building industry is under pressure to introduce more variety to its customers of new buildings. Ozaki (2003) stated that house builders in the UK for some time have searched for ways to be more customer oriented. Noguchi (2003) argued that the Japanese housing industry previously focused on a mass production approach, but has, by using a qualityoriented approach, succeeded to improve customer satisfaction and quality through the use of mass customization. Durdyev et al. (2018) studied the influence of service quality on construction clients' satisfaction and found a positive relationship. In a similar study, Forsythe (2016) studied the impact of service quality on customer satisfaction in the house building industry. The study found that customers, although focusing on price during the construction stage, expected a high level of service quality as well. Lastly, Torbica and Stroh (2001) proposed a three-dimensional model to describe customer satisfaction. They found that house design, house quality, and service are significant predictors of customer satisfaction for house buyers. Forsythe (2015) demonstrated similar results. The ability to be familiar with customer preferences is for that reason of significant importance to develop a quality-orientated approach to improve customer 
satisfaction in the house building industry. Gibler and Tyvimaa (2014) studied customer segmentation in the Finnish housing industry and identified at least four different customer types with different housing requirements and preferences. They found that the customer type "homebodies" preferred low- to midpriced multifamily houses placed in peaceful suburban areas. Customers of the type "actives" preferred penthouse apartments and buildings with lake view placed in high-priced exclusive locations, whereas the customer type "isolated wolves" preferred affordable functional single houses in less affluent suburban locations, and "funlovers" preferred small apartments within the urban center of cities. To create enough variety at an acceptable cost, Hofman et al. (2006) found that customers generally prefer options to select from, but if the options affect the price significantly, a reduced level of customization was registered. Furthermore, Hofman et al. (2006) concluded that the ability to modularize a product portfolio is of great importance to offer various solutions to customers. Leishman and Warren (2006) found that companies offering only house types of one certain size have a smaller variation compared with volume builders that offer a greater range of house types. Furthermore, a positive impact from the amount of house type offered to customers and level of customer satisfaction was identified.

\section{DISCUSSION}

The aim of this research was to explore existing research on mass customization in the house building industry to identify gaps in the research area and thereby identify potential research directions. Therefore, a three-stage literature review was applied to review state-of-the-art literature. The findings of the literature review clearly indicate that there exists a potential for utilizing mass customization in the house building industry owing to mass customization's ability to lower unit costs, increase quality, and shorten project duration, while at the same time allowing customization. However, research on mass customization as a business strategy within the house building industry is scarce and therefore a highly unexplored research field.

Mass customization is considered relevant to apply in the construction industry to improve today's house production. Concurrently, automation technologies are emerging to support the industrialization of house production (Bock, 2015). In the manufacturing industry, automation technology and digital production have had a great impact on industrialization and the ability to mass customize offerings. However, considering the limited prior use of industrialization techniques in the

\section{REFERENCES}

Adinyira, E., Kwofie, T. E., and Quarcoo, F. (2018). Stakeholder requirements for building energy efficiency in mass housing delivery: the house of quality approach. Environ. Dev. Sustain. 20, 1115-1131. doi: 10.1007/s10668-017-9930-z

Alwisy, A., Hamdan, S. B., Barkokebas, B., Bougerguene, A., and Al-Hussein, M. (2018). A bim-based automation of design and drafting for manufacturing of construction industry, this may explain the limited use of automation and digitalization in the industry today despite the potential being high. By implementing a mass customization strategy, this might enable construction companies to increase the level of automation and digitalization due to the introduction of a higher level of standardization on products and processes. Future research might therefore look into the role of automation and digitalization in relation to mass customization in the house building industry to further explore the potential.

Much of the existing research on mass customization in the house building industry is related to case studies, planning activities, and mass customization as a strategy. However, as previously described, companies must develop three fundamental, operational capabilities to become a mass customizer, which are solution space development, robust process design, and choice navigation. Therefore, research related to the three capabilities is considered relevant to the research field. When analyzing the identified literature, it is found that robust process design is the most studied capability, whereas research on solution space development and choice navigation is scarce. Therefore, future research should investigate these two capabilities further to support the implementation and operationalization of mass customization in the house building industry.

Based on the findings of this literature review, it can be concluded that history has implied that customers' perception of industrialized housing is negative. Despite this, industrialization techniques have been proven to, among others, improve quality and decrease construction time, waste, and costs in the house building industry. Through the findings of the literature review, a potential for applying mass customization in the house building industry has been proven. However, as the findings also show, the potential is at present unexploited. Several challenges for implementing mass customization in the house building industry have been identified. One of the identified challenges is the requirement for changing the supply chain setup. At the moment, supply chains in the house building industry are structured to fit engineer-to-order building projects and thus lack standards necessary to cope with builders and suppliers of mass-customized offerings. Another identified challenge is to align what customers want with the internal capabilities of the company, that is, to define the solution space offered to customers.

\section{AUTHOR CONTRIBUTIONS}

ML, JL, and SL have in collaboration conducted the literature review. TB and $\mathrm{KN}$ have contributed through supervision. wood panels for modular residential buildings. Int. J. Constr. Manag. 19, 1-19. doi: $10.1080 / 15623599.2018 .1462446$

Anson, M., Ko, J., and Lam, E. (2002). "Industrialized housing constructionthe UK experience," in Advances in Building Technology: Proceedings of the International Conference on Advances in Building Technology (Hong Kong: Elsevier Science), 383.

Anvari, B., Angeloudis, P., and Ochieng, W. (2016). A multi-objective GAbased optimisation for holistic manufacturing, transportation and assembly of 
precast construction. Automat. Constr. 71, 226-241. doi: 10.1016/j.autcon.2016. 08.007

Arashpour, M., Wakefield, R., Blismas, N., and Maqsood, T. (2015). Autonomous production tracking for augmenting output in off-site construction. Automat. Constr. 53, 13-21. doi: 10.1016/j.autcon.2015.03.013

Assaf, S. A., and Al-Hejji, S. (2006). Causes of delay in large construction projects. Int. J. Project Manag. 24, 349-357. doi: 10.1016/j.ijproman.2005.11.010

Ball, M. (1999). Chasing a snail: innovation and housebuilding firms' strategies. Housing Stud. 14, 9-22. doi: 10.1080/02673039982975

Barlow, J. (1999). From craft production to mass customisation. Innovation requirements for the UK housebuilding industry. Housing Stud. 14, 23-42. doi: 10.1080/02673039982984

Barlow, J., Childerhouse, P., Gann, D., Hong-Minh, S., Naim, M., and Ozaki, R. (2003). Choice and delivery in housebuilding: lessons from Japan for UK housebuilders. Build. Res. Inf. 31, 134-145. doi: 10.1080/09613210 302003

Barman, S., and Canizares, A. E. (2015). A survey of mass customization in practice. Int. J. Supply Chain Manag. 4, 65-72.

Behera, P., Mohanty, R., and Prakash, A. (2015). Understanding construction supply chain management. Prod. Plann. Contr. 26, 1332-1350. doi: 10.1080/09537287.2015.1045953

Benros, D., and Duarte, J. (2009). An integrated system for providing mass customized housing. Automat. Constr. 18, 310-320. doi: 10.1016/j.autcon.2008.09.006

Bergström, M., and Stehn, L. (2005). Matching industrialised timber frame housing needs and enterprise resource planning: a change process. Int. J. Prod. Econ. 97, 172-184. doi: 10.1016/j.ijpe.2004.06.052

Berman, B. (2002). Should your firm adopt a mass customization strategy? Bus. Horiz. 45, 51-60. doi: 10.1016/S0007-6813(02)00227-6

Blismas, N., Pasquire, C., and Gibb, A. (2006). Benefit evaluation for off-site production in construction. Constr. Manag. Econ. 24, 121-130. doi: 10.1080/01446190500184444

Boafo, F. E., Kim, J. H., and Kim, J. T. (2016). Performance of modular prefabricated architecture: case study-based review and future pathways. Sustainability 8, 1-16. doi: 10.3390/su8060558

Bock, T. (2015). The future of construction automation: technological disruption and the upcoming ubiquity of robotics. Automat. Constr. 59, 113-121. doi: 10.1016/j.autcon.2015.07.022

Buffington, J. (2011). Comparison of mass customization and generative customization in mass markets. Ind. Manag. Data Syst. 111, 41-62. doi: 10.1108/02635571111099721

Chen, K., and Lu, W. (2018). Design for manufacture and assembly oriented design approach to a curtain wall system: a case study of a commercial building in Wuhan, China. Sustainability 10:2211. doi: 10.3390/su10072211

Choi, J. O., Chen, X. B., and Kim, T. W. (2019). Opportunities and challenges of modular methods in dense urban environment. Int. J. Constr. Manag. 19, 93-105. doi: 10.1080/15623599.2017.1382093

Construction Industry Institute Research, Team (2009). Project Definition Rating Index-Industrial Projects, Version 3.2. Austin, TX: Construction Industry Institute.

Coronado, A. E., Lyons, A. C., Kehoe, D. F., and Coleman, J. (2004). Enabling mass customization: extending build-to-order concepts to supply chains. Prod. Plann. Contr. 15, 398-411. doi: 10.1080/095372804200023 8809

Craig, D., and Roy, R. (2004). Developing a customer-focused culture in the speculative house-building industry. Total Qual. Manag. Bus. Excell. 15, 73-87. doi: 10.1080/1478336032000149117

Daud, M. N., Hamzah, H., and Adnan, Y. M. (2012). Examining the potential for mass customization of housing in Malaysia. Open House Int. 37, 16-27.

Doran, D., and Giannakis, M. (2011). An examination of a modular supply chain: a construction sector perspective. Supply Chain Manag. 16, 260-270. doi: $10.1108 / 13598541111139071$

Du, X., Jiao, J., and Tseng, M. M. (2006). Understanding customer satisfaction in product customization. Int. J. Adv. Manufact. Technol. 31, 396-406. doi: 10.1007/s00170-005-0177-8

Durdyev, S., Ihtiyar, A., Banaitis, A., and Thurnell, D. (2018). The construction client satisfaction model: a PLS-SEM approach. J. Civil Eng. Manag. 24, 31-42. doi: $10.3846 /$ jcem. 2018.297
Erixon, G. (1998). Modular Function Deployment: A Method for Product Modularisation. Stockholm: Royal Institute of Technology, Department of Manufacturing Systems, Assembly Systems Division.

Flyvbjerg, B., Holm, M. S., and Buhl, S. (2002). Underestimating costs in public works projects: error or lie? J. Am. Plann. Assoc. 68, 279-295. doi: $10.1080 / 01944360208976273$

Forsythe, P. (2015). Monitoring customer perceived service quality and satisfaction during the construction process. Constr. Econ. Build. 15, 19-42. doi: 10.5130/AJCEB.v15i1.4172

Forsythe, P. J. (2016). Construction service quality and satisfaction for a targeted housing customer. Eng. Constr. Architect. Manag. 23, 323-348. doi: 10.1108/ECAM-05-2015-0076

Franke, N., Schreier, M., and Kaiser, U. (2010). The "I designed it myself" effect in mass customization. Manag. Sci. 56, 125-140. doi: 10.1287/mnsc.1090.1077

Frutos, J. D., and Borenstein, D. (2003). Object-oriented model for customerbuilding company interaction in mass customization environment. J. Constr. Eng. Manag. 129, 302-313. doi: 10.1061/(ASCE)0733-9364(2003)129:3(302)

Gann, D. M. (1996). Construction as a manufacturing process? Similarities and differences between industrialized housing and car production in Japan. Constr. Manag. Econ. 14, 437-450. doi: 10.1080/014461996373304

Gibb, A. (1999). Off-Site Fabrication-Pre-assembly, Prefabrication and Modularisation. New York, NY: John Wiley and Sons Inc.

Gibb, A., and Isack, F. (2003). Re-engineering through pre-assembly: client expectations and drivers. Build. Res. Inf. 31, 146-160. doi: 10.1080/09613210302000

Gibler, K. M., and Tyvimaa, T. (2014). The potential for consumer segmentation in the Finnish housing market. J. Cons. Aff. 48, 351-379. doi: 10.1111/joca.12037

Gilmore, J. H., and Pine, B. J. (1997). The four faces of mass customization. Harv. Bus. Rev. 75, 91-101.

Goodier, C., and Gibb, A. (2007). Future opportunities for offsite in the UK. Constr. Manag. Econ. 25, 585-595. doi: 10.1080/01446190601071821

Gosling, J., Pero, M., Schoenwitz, M., Towill, D., and Cigolini, R. (2016). Defining and categorizing modules in building projects: an international perspective. J. Constr. Eng. Manag. 142:04016062. doi: 10.1061/(ASCE)CO.1943-7862.0001181

Haas, C. T., O'connor, J. T., Tucker, R., Eickmann, J., and Fagerlund, W. R. (2000). Prefabrication and Preassembly Trends and Effects on the Construction Workforce. Report 14, Center for Construction Industry Studies, University of Texas at Austin.

Halman, J. I., and Voordijk, J. T. (2012). Balanced framework for measuring performance of supply chains in house building. J. Constr. Eng. Manag. 138, 1444-1450. doi: 10.1061/(ASCE)CO.1943-7862.0000553

Halman, J. I., Voordijk, J. T., and Reymen, I. M. (2008). Modular approaches in Dutch house building: an exploratory survey. Housing Stud. 23, 781-799. doi: 10.1080/02673030802293208

Hanif, H., Khurshid, M. B., Lindhard, S. M., and Aslam, Z. (2016). Impact of variation orders on time and cost in mega hydropower projects of Pakistan. J. Constr. Dev. Countr. 21, 37-53. doi: 10.21315/jcdc2016.21.2.3

Hofman, E., Halman, J. I., and Ion, R. A. (2006). Variation in housing design: identifying customer preferences. Housing Stud. 21, 929-943. doi: 10.1080/02673030600917842

Hofman, E., Voordijk, H., and Halman, J. (2009). Matching supply networks to a modular product architecture in the house-building industry. Build. Res. Inf. 37, 31-42. doi: 10.1080/09613210802628003

Höök, M., and Stehn, L. (2008). Applicability of lean principles and practices in industrialized housing production. Constr. Manag. Econ. 26, 1091-1100. doi: 10.1080/01446190802422179

Huang, C., and Kusiak, A. (1998). Modularity in design of products and systems. IEEE Trans. Syst. Man Cybern. B Cybern. 28, 66-77. doi: 10.1109/3468.650323

Huang, X., Kristal, M. M., and Schroeder, R. G. (2010). The impact of organizational structure on mass customization capability: a contingency view. Prod. Oper. Manag. 19, 515-530. doi: 10.1111/j.1937-5956.2009.01117.x

Hwang, B.-G., Shan, M., and Looi, K.-Y. (2018). Key constraints and mitigation strategies for prefabricated prefinished volumetric construction. J. Clean. Prod. 183, 183-193. doi: 10.1016/j.jclepro.2018.02.136

Isaac, S., Bock, T., and Stoliar, Y. (2016). A methodology for the optimal modularization of building design. Automat. Constr. 65, 116-124. doi: 10.1016/j.autcon.2015.12.017 
Jaillon, L., and Poon, C. (2010). Design issues of using prefabrication in Hong Kong building construction. Constr. Manag. Econ. 28, 1025-1042. doi: 10.1080/01446193.2010.498481

Jaillon, L., and Poon, C. S. (2009). The evolution of prefabricated residential building systems in Hong Kong: a review of the public and the private sector. Automat. Constr. 18, 239-248. doi: 10.1016/j.autcon.2008.09.002

Jensen, K. N., Nielsen, K., Brunoe, T. D., and Lindhard, S. M. (2017). "Mass customization in the building and construction industry," in Managing Complexity (Springer Proceedings in Business and Economics), 1-12. doi: 10.1007/978-3-319-29058-4_1

Jensen, P., Olofsson, T., and Johnsson, H. (2012). Configuration through the parameterization of building components. Automat. Constr. 23, 1-8. doi: 10.1016/j.autcon.2011.11.016

Ji, Y., Zhu, F., Li, H. X., and Al-Hussein, M. (2017). Construction industrialization in China: current profile and the prediction. Appl. Sci. 7:180. doi: 10.3390/app7020180

Jiang, L., Li, Z., Li, L., and Gao, Y. (2018). Constraints in the promotion of prefabricated construction in China. Sustainability 10:2516. doi: $10.3390 /$ su10072516

Jin, R., Gao, S., Cheshmehzangi, A., and Aboagye-Nimo, E. (2018). A holistic review of off-site construction literature published between 2008 and 2018. J. Clean. Prod. 202, 1202-1219. doi: 10.1016/j.jclepro.2018.08.195

Jose, A., and Tollenaere, M. (2005). Modular and platform methods for product family design: literature analysis. J. Intell. Manuf. 16, 371-390. doi: 10.1007/s10845-005-7030-7

Josephson, P., and Hammarlund, Y. (1999). The causes and costs of defects in construction: a study of seven building projects. Automat. Constr. 8, 681-687. doi: $10.1016 /$ S0926-5805(98)00114-9

Kamali, M., and Hewage, K. (2016). Life cycle performance of modular buildings: a critical review. Renew. Sust. Energy Rev. 62, 1171-1183. doi: 10.1016/j.rser.2016.05.031

Kazaz, A., Ulubeyli, S., and Tuncbilekli, N. A. (2012). Causes of delays in construction projects in Turkey. J. Civil Eng. Manag. 18, 426-435. doi: $10.3846 / 13923730.2012 .698913$

Lampel, J., and Mintzberg, H. (1996). Customizing customization. Sloan Manag. Rev. 38:21.

Lawson, R. M., Ogden, R. G., and Bergin, R. (2011). Application of modular construction in high-rise buildings. J. Architect. Eng. 18, 148-154. doi: 10.1061/(ASCE)AE.1943-5568.0000057

Lee, S., and Ha, M. (2013). Customer interactive building information modeling for apartment unit design. Automat. Constr. 35, 424-430. doi: 10.1016/j.autcon.2013.05.026

Leishman, C., and Warren, F. (2006). Private housing design customization through house type substitution. Constr. Manag. Econ. 24, 149-158. doi: $10.1080 / 01446190500204754$

Levy, Y., and Ellis, T. J. (2006). A systems approach to conduct an effective literature review in support of information systems research. Inf. Sci. 9, 181-212. doi: $10.28945 / 479$

Li, H. X., Al-Hussein, M., Lei, Z., and Ajweh, Z. (2013). Risk identification and assessment of modular construction utilizing fuzzy analytic hierarchy process (AHP) and simulation. Canad. J. Civil Eng. 42, 1184-1195. doi: 10.1139/cjce-2013-0013

Li, X., Shen, G. Q., Wu, P., and Yue, T. (2019). Integrating building information modeling and prefabrication housing production. Automat. Constr. 100, 46-60. doi: 10.1016/j.autcon.2018.12.024

Lindhard, S., and Wandahl, S. (2014). Exploration of the reasons for delays in construction. Int. J. Constr. Manag. 14, 36-44. doi: 10.1080/15623599.2013.875267

Linner, T., and Bock, T. (2012). Evolution of large-scale industrialisation and service innovation in Japanese prefabrication industry. Constr. Innov. 12, 156-178. doi: 10.1108/14714171211215921

Liu, K., Su, Y., and Zhang, S. (2018). Evaluating supplier management maturity in prefabricated construction project-survey analysis in China. Sustainability 10:3046. doi: 10.3390/su10093046

Love, P. E. (2002). Influence of project type and procurement method on rework costs in building construction projects. J. Constr. Eng. Manag. 128, 18-29. doi: 10.1061/(ASCE)0733-9364(2002)128:1(18)
Love, P. E., Irani, Z., and Edwards, D. J. (2004). A seamless supply chain management model for construction. Supply Chain Manag. 9, 43-56. doi: 10.1108/13598540410517575

Lu, W., Chen, K., Xuw, F., and Pan, W. (2018). Searching for an optimal level of prefabrication in construction: an analytical framework. J. Clean. Prod. 201, 236-245. doi: 10.1016/j.jclepro.2018.07.319

Mahapatra, K., Gustavsson, L., and Hemström, K. (2012). Multi-storey woodframe buildings in Germany, Sweden, and the UK. Constr. Innov. 12, 62-85. doi: $10.1108 / 14714171211197508$

Mello, M. H., Strandhagen, J. O., and Alfnes, E. (2015). Analyzing the factors affecting coordination in engineer-to-order supply chain. Int. J. Operat. Prod. Manag. 35, 1005-1031. doi: 10.1108/IJOPM-12-2013-0545

Minunnu, R., O'grady, T., Morrison, G. M., Gruner, R. L., and Colling, M. (2018). Strategies for applying the circular economy to prefabricated buildings. Buildings 8:125. doi: 10.3390/buildings8090125

Moghimi, V., Jusan, M. B. M., Izadpanahi, P., and Mahdinejad, J. (2017). Incorporating user values into housing design through indirect user participation using MEC-QFD model. J. Build. Eng. 9, 76-83. doi: $10.1016 /$ j.jobe.2016.11.012

Nadim, W., and Goulding, J. S. (2011). Offsite production: a model for building down barriers: a European construction industry perspective. Eng. Constr. Architect. Manag. 18, 82-101. doi: 10.1108/09699981111098702

Nahmens, I., and Bindroo, V. (2011). Is customization fruitful in industrialized homebuilding industry? J. Constr. Eng. Manag. 137, 1027-1035. doi: 10.1061/(ASCE)CO.1943-7862.0000396

Nahmens, I., and Mullens, M. (2009). The impact of product choice on lean homebuilding. Constr. Innov. 9, 84-100. doi: 10.1108/14714170910931561

Nguyen, L. D., Ogunlana, S. O., and Lan, D. T. X. (2004). A study on project success factors in large construction projects in Vietnam. Eng. Constr. Architect. Manag. 11, 404-413. doi: 10.1108/09699980410570166

Nicholas, J. M., and Steyn, H. (2017). Project Management for Engineering Business and Technology. Abingdon: Taylor \& Francis.

Nielsen, K., Brunoe, T. D., Jensen, K. N., and andersen, A. L. (2017). "Utilization of mass customization in construction and building industry," in Managing Complexity. Springer Proceedings in Business and Economics, 115-125. doi: 10.1007/978-3-319-29058-4_9

Noguchi, M. (2003). The effect of the quality-oriented production approach on the delivery of prefabricated homes in Japan. J. Hous. Built Environ. 18, 353-364. doi: 10.1023/B:JOHO.0000005759.07212.00

O'connor, J. T., O'brien, W. J., and Choi, J. O. (2014). Critical success factors and enablers for optimum and maximum industrial modularization. J. Constr. Eng. Manag. 140:04014012. doi: 10.1061/(ASCE)CO.1943-7862.00 00842

Olawale, Y. A., and Sun, M. (2010). Cost and time control of construction projects: inhibiting factors and mitigating measures in practice. Constr. Manag. Econ. 28 509-526. doi: 10.1080/01446191003674519

Onori, M., Martinez, S., Jardon, A., Navarro, J. M., and Gonzalez, P. (2008). Building industrialization: robotized assembly of modular products. Assembly Autom. 28, 134-142. doi: 10.1108/01445150810863716

Ozaki, R. (2003). Customer-focused approaches to innovation in housebuilding. Constr. Manag. Econ. 21, 557-564. doi: 10.1080/0144619032000134093

Pan, W., Gibb, A. G., and Dainty, A. R. (2008). Leading UK housebuilders' utilization of offsite construction methods. Build. Res. Inf. 36, 56-67. doi: 10.1080/09613210701204013

Pero, M., Stösslein, M., and Cigolini, R. (2015). Linking product modularity to supply chain integration in the construction and shipbuilding industries. Int J. Prod. Econ. 170, 602-615. doi: 10.1016/j.ijpe.2015.05.011

Pine, B. J. (1993). Mass Customization: the New Frontier in Business Competition. Boston, MA: Harvard Business Press.

Pine, B. J., Victor, B., and Boynton, A. (1993, September-October). Making mass customization work. Harvard Business Review p. 108-116.

Ramaji, I. J., and Memari, A. M. (2016). Product architecture model for multistory modular buildings. J. Constr. Eng. Manag. 142:04016047. doi: 10.1061/(ASCE)CO.1943-7862.0001159

Richard, R. (2005). Industrialised building systems: reproduction before automation and robotics. Automat. Constr. 14, 442-451. doi: 10.1016/j.autcon.2004.09.009 
Roy, R., Brown, J., and Gaze, C. (2003). Re-engineering the construction process in the speculative house-building sector. Constr. Manag. Econ. 21, 137-146. doi: 10.1080/0144619032000049674

Sacks, R., and Partouche, R. (2009). Empire state building project: archetype of "mass construction." J. Constr. Eng. Manag. 136, 702-710. doi: 10.1061/(ASCE)CO.1943-7862.0000162

Salama, T., Salah, A., Moselhi, O., and Al-Hussein, M. (2017). Near optimum selection of module configuration for efficient construction. Automat. Constr. 83, 316-329. doi: 10.1016/j.autcon.2017.03.008

Salvador, F., De Holan, P. M., and Piller, F. T. (2009). Cracking the code of mass customization. MIT Sloan Manag. Rev. 50:71.

Schoenwitz, M., Naim, M., and Potter, A. (2012). The nature of choice in mass customized house building. Constr. Manag. Econ. 30, 203-219. doi: 10.1080/01446193.2012.664277

Senghore, O., Hastak, M., Abdelhamid, T., Abuhammad, A., and Syal, M. (2004). Production process for manufactured housing. J. Constr. Eng. Manag. 130, 708-718. doi: 10.1061/(ASCE)0733-9364(2004)130:5(708)

Sharafi, P., Rashidi, M., Samali, B., Ronagh, H., and Mortazavi, M. (2018). Identification of factors and decision analysis of the level of modularization in building construction. J. Architect. Eng. 24:04018010. doi: 10.1061/(ASCE)AE.1943-5568.0000313

Song, J., Fagerlund, W. R., Haas, C. T., Tatum, C. B., and Vanegas, J. A. (2005). Considering prework on industrial projects. J. Constr. Eng. Manag. 131, 723-733. doi: 10.1061/(ASCE)0733-9364(2005)131:6(723)

Tam, V. W., Tam, C. M., Zeng, S., and Ng, W. C. (2007). Towards adoption of prefabrication in construction. Build. Environ. 42, 3642-3654. doi: 10.1016/j.buildenv.2006.10.003

Tatum, C., Vanegas, J. A., and Williams, J. (1987). Constructability Improvement Using Prefabrication, Preassembly, and Modularization. Austin, TX: Bureau of Engineering Research; University of Texas at Austin.

Thuesen, C., and Hvam, L. (2011). Efficient on-site construction: learning points from a German platform for housing. Constr. Innov. 11, 338-355. doi: 10.1108/14714171111149043

Torbica, ŽM., and Stroh, R. C. (2001). Customer satisfaction in home building. J. Constr. Eng. Manag. 127, 82-86. doi: 10.1061/(ASCE)0733-9364(2001)1 27:1(82)

Tseng, M. M., and Piller, F. T. (2003). The Customer Centric Enterprise. Heidelberg: Springer.

Ulrich, K. (1994). "Fundamentals of product modularity," in Management of Design (New York, NY: Springer), 219-231.
Veenstra, V. S., Halman, J. I., and Voordijk, J. T. (2006). A methodology for developing product platforms in the specific setting of the housebuilding industry. Res. Eng. Design 17, 157-173. doi: 10.1007/s00163-0060022-6

Viana, D. D., Tommelein, I. D., and Formoso, C. T. (2017). Using modularity to reduce complexity of industrialized building systems for mass customization. Energies 10, 2-17. doi: 10.3390/en10101622

Warren-Myers, G., and Heywood, C. (2018). A new demand-supply model to enable sustainability in new Australian housing. Sustainability 10:376. doi: $10.3390 /$ su10020376

Winch, G. (2003). Models of manufacturing and the construction process: the genesis of re-engineering construction. Build. Res. Inf. 31, 107-118. doi: 10.1080/09613210301995

Wu, P., Xu, Y., Jin, R., Lu, Q., Madgwick, D., and Hancock, C. M. (2019). Perceptions towards risks involved in off-site construction in the integrated design \& construction project delivery. J. Clean. Prod. 213, 899-914. doi: 10.1016/j.jclepro.2018.12.226

Yashiro, T. (2014). Conceptual framework of the evolution and transformation of the idea of the industrialization of building in Japan. Constr. Manag. Econ. 32, 16-39. doi: 10.1080/01446193.2013.8 64779

Yu, H., Tweed, T., Al-Hussein, M., and Nasseri, R. (2009). Development of lean model for house construction using value stream mapping. J. Constr. Eng. Manag. 135, 782-790. doi: 10.1061/(ASCE)0733-9364(2009)135: 8(782)

Yuan, Z., Sun, C., and Wang, Y. (2018). Design for manufacture and assemblyoriented parametric design of prefabricated buildings. Automat. Constr. 88, 13-22. doi: 10.1016/j.autcon.2017.12.021

Conflict of Interest: The authors declare that the research was conducted in the absence of any commercial or financial relationships that could be construed as a potential conflict of interest.

Copyright (C) 2019 Larsen, Lindhard, Brunoe, Nielsen and Larsen. This is an openaccess article distributed under the terms of the Creative Commons Attribution License (CC BY). The use, distribution or reproduction in other forums is permitted, provided the original author(s) and the copyright owner(s) are credited and that the original publication in this journal is cited, in accordance with accepted academic practice. No use, distribution or reproduction is permitted which does not comply with these terms. 